Business Metrics for High-Performance Homes:

A Colorado Springs Case Study

R. Beach and A. Jones IBACOS, Inc. 


\section{NOTICE}

This report was prepared as an account of work sponsored by an agency of the United States government. Neither the United States government nor any agency thereof, nor any of their employees, subcontractors, or affiliated partners makes any warranty, express or implied, or assumes any legal liability or responsibility for the accuracy, completeness, or usefulness of any information, apparatus, product, or process disclosed, or represents that its use would not infringe privately owned rights. Reference herein to any specific commercial product, process, or service by trade name, trademark, manufacturer, or otherwise does not necessarily constitute or imply its endorsement, recommendation, or favoring by the United States government or any agency thereof. The views and opinions of authors expressed herein do not necessarily state or reflect those of the United States government or any agency thereof.

Available electronically at SciTech Connect http:/www.osti.gov/scitech

Available for a processing fee to U.S. Department of Energy

and its contractors, in paper, from:

U.S. Department of Energy

Office of Scientific and Technical Information

P.O. Box 62

Oak Ridge, TN 37831-0062

OSTI http://www.osti.gov

Phone: 865.576.8401

Fax: 865.576.5728

Email: reports@osti.gov

Available for sale to the public, in paper, from:

U.S. Department of Commerce

National Technical Information Service

5301 Shawnee Road

Alexandria, VA 22312

NTIS http://www.ntis.gov

Phone: 800.553 .6847 or 703.605 .6000

Fax: 703.605.6900

Email: orders@ntis.gov 


\title{
Business Metrics for High-Performance Homes: A Colorado Springs Case Study
}

\author{
Prepared for: \\ The National Renewable Energy Laboratory \\ On behalf of the U.S. Department of Energy's Building America Program \\ Office of Energy Efficiency and Renewable Energy \\ 15013 Denver West Parkway \\ Golden, CO 80401 \\ NREL Contract No. DE-AC36-08GO28308 \\ Prepared by: \\ R. Beach and A. Jones \\ IBACOS, Inc. \\ 2214 Liberty Avenue \\ Pittsburgh, PA 15222 \\ NREL Technical Monitor: Stacey Rothgeb \\ Prepared under Subcontract No. KNDJ-0-40341-05
}

April 2016 
The work presented in this report does not represent performance of any product relative to regulated minimum efficiency requirements.

The laboratory and/or field sites used for this work are not certified rating test facilities. The conditions and methods under which products were characterized for this work differ from standard rating conditions, as described.

Because the methods and conditions differ, the reported results are not comparable to rated product performance and should only be used to estimate performance under the measured conditions. 


\section{Contents}

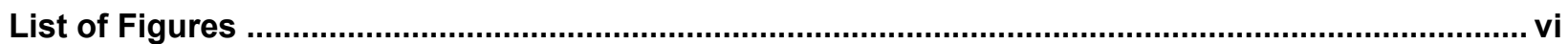

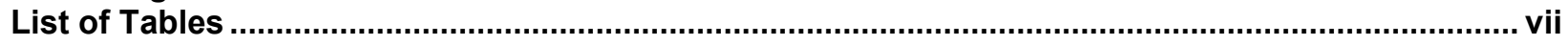

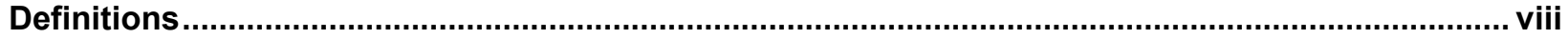

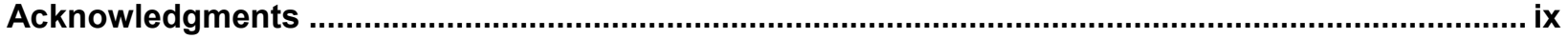

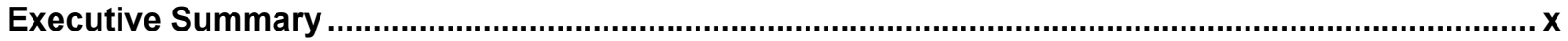

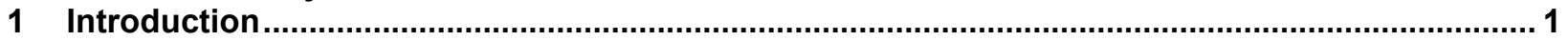

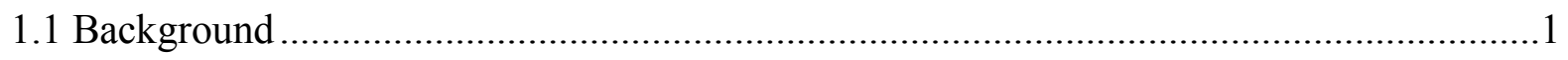

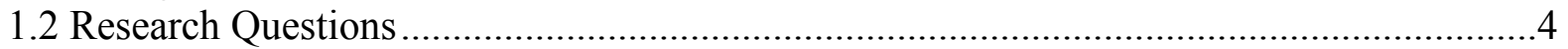

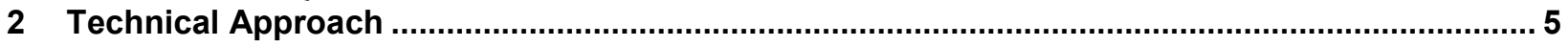

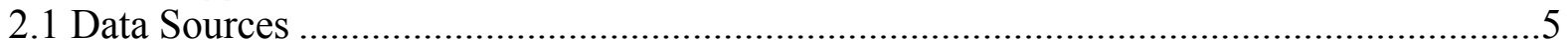

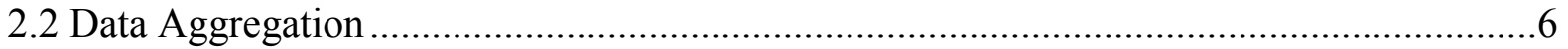

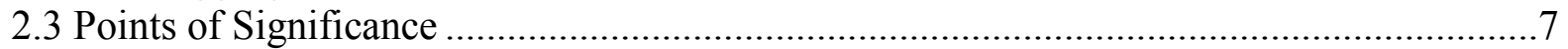

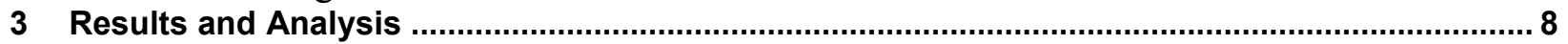

3.1 Home Energy Ratings in Colorado Springs...............................................................

3.2 Variations in Market Share of Builders and Energy Efficiency .................................... 10

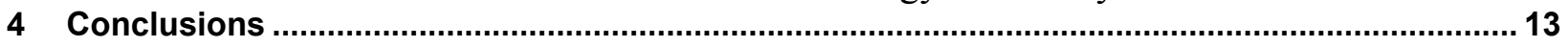

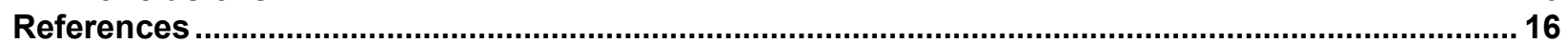




\section{List of Figures}

Figure 1. Number of new home closings per quarter in Colorado Springs, Colorado (2005-2013)... 8 Figure 2. Number of ENERGY STAR certifications on new homes in Colorado Springs, Colorado (2006-2013)

Figure 3. Number of HERS-rated new homes in Colorado Springs, Colorado (2006-2013) 8

Figure 4. Fraction of new homes that were HERS rated in Colorado Springs, Colorado (2006-2013)

Figure 5. Number of active builders in Colorado Springs, Colorado (2005-2013)

Figure 6. Number of builders actively having HERS ratings performed in Colorado Springs, Colorado (2006-2013)

Figure 7. Percentage of active builders performing at least two HERS ratings in Colorado Springs, Colorado (2006-2013)

Unless otherwise noted, all figures and photos were created by IBACOS. 


\section{List of Tables}

Table 1. Division of Market between Energy-Efficient and Standard Builders, Pre- and Post-

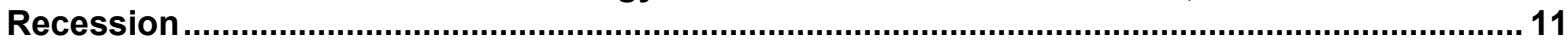

Table 2. Survival of Builders Post-Recession and Whether They Performed Energy Ratings......... 12

Unless otherwise noted, all tables were created by IBACOS. 


\section{Definitions}

$\begin{array}{ll}\text { HERS }^{\circledR} & \text { Home Energy Rating System } \\ \text { NAHB } & \text { National Association of Home Builders } \\ \text { RESNET } & \text { Residential Energy Services Network }\end{array}$




\section{Acknowledgments}

The authors acknowledge EnergyLogic, Built Green Colorado, and Metrostudy for providing the data used in this study and EnergyLogic and Built Green Colorado for contributing anecdotal information to the analysis. 


\section{Executive Summary}

Energy efficiency has been a growing feature of new homes in the United States for some time. During the last decade, the energy rating industry has matured with more stringent metrics and increased market share. The specific methods and processes for achieving energy efficiency have evolved and fluctuated in terms of their approach and saturation in the marketplace.

The building industry needs to understand how energy ratings can impact homebuilders. Of interest is how energy efficiency may or may not have a positive impact on homebuilders' business success. Focusing on Colorado Springs, Colorado, as a case study, the U.S. Department of Energy's Building America research team IBACOS suggests a win-win between a builder's investment in energy efficiency and that builder's ability to sell homes. Although this research did not ultimately determine why a correlation may exist, a builder's investment in voluntary energy-efficiency programs correlated with that builder's ability to survive the Great Recession of 2007 to 2009 (Hall 2010). This report explores the relationship between energy-efficiency ratings and the market performance of several builders in Colorado Springs.

More specifically, this research documents the market performance of homebuilders in Colorado Springs from 2005 through 2013 as it relates to voluntary energy-efficiency programs such as ENERGY STAR ${ }^{\circledR}$ for Homes and the Home Energy Rating System. During this time, the U.S. builder community was devastated by the Great Recession and experienced major drop-offs in home sales. The Colorado Springs market saw more than a 50\% drop-off in quarterly home sales, which ultimately led to the exit of six large builders from the region.

The home energy rating industry in the area also saw great change during the Recession. During the contraction of the housing market between 2007 and 2009, energy ratings reached record market share as monetary incentives and programs sought to grow energy efficiency and as builders panicked to differentiate themselves to survive the most difficult economic conditions since the Great Depression of the 1930s. With support of the Built Green program, the ENERGY STAR program in Colorado Springs saw massive growth during this period of time. It reached a peak market share of $25 \%$ of newly constructed homes in 2010 , which was in line with national trends.

A key finding of this research is a positive correlation between builders' survival of the Great Recession and their investment in energy-efficiency development of their products. The builders that invested in energy efficiency were less likely to lose market share than those that did not. However, this study does not determine the exact causes for that survival to pinpoint how those builders may have differentiated themselves to buyers. Did the energy ratings influence survivability? Was it the marketing of their "green" building practices? Or was it the benefit of third-party oversight, which led to higher-quality construction practices, which in turn led buyers to prefer these homes? This discussion needs to continue to further develop the relationship between builders and energy-efficiency providers. 


\section{Introduction}

Research has demonstrated the increased value of energy-efficient homes and market price differentiation from standard homes, as well as how consumers seem to be responding to them. Although energy-efficient homes continue to gain ground in the larger housing market, little is known about the business performance of the builders that build these homes. The U.S. Department of Energy's Building America research team IBACOS seeks to address the question in this report: Do builders of energy-efficient homes translate the investment in energy efficiency into better business performance than builders of less energy-efficient homes?

To answer this question, IBACOS focused on one measure of energy efficiency: the Residential Energy Services Network (RESNET) Home Energy Rating System (HERS ${ }^{\circledR}$ ) Index, a scalar measurement of a home's energy efficiency relative to a standard reference home (RESNET 2013). By evaluating a data set of builders in the Colorado Springs, Colorado, market where some homes were assigned a HERS Index score through a standard HERS rating process (RESNET 2013) and other homes were not HERS rated, IBACOS established the significance of the HERS rating to the business success of the builders in that market. Specifically, IBACOS examined the influence of the HERS rating on the sales velocity (rate of home closings) and market share of each builder in the data set. Attention also was given to the effect of the Great Recession (2007 to 2009) (Hall 2010) on the business success of these builders. Anecdotal evidence from a local HERS rater also was collected to provide subjective validation of the primary data analysis.

Whether builders of energy-efficient homes are experiencing a competitive advantage over standard builders is important for the future of the housing industry. Professionals in the housing market would benefit from a better understanding of this correlation. Also, builders may be more inclined to enter the energy-efficient home market after seeing positive market effects.

\subsection{Background}

Several research studies have already been conducted to demonstrate the value of energyefficient homes and their sales prices compared to the sales prices of standard homes. These studies, along with other studies that explore how consumers seem to be responding to the perceived increase in value between standard and energy-efficient homes, are mentioned below. However, no research has provided an understanding of the business success of energy-efficient homebuilders. This project seeks to evaluate the correlation between energy efficiency (represented by the HERS Index) and market performance (defined by market share and sales velocity) of builders.

Several studies recently have been published on energy-efficient housing related to market acceptance and value. These studies revealed correlations that are developing between energyefficient homes, their value compared to standard homes, and consumer interest and market acceptance (Lande 2007; Galuppo and Tu 2010). Bloom et al. (2011) used the ENERGY STAR ${ }^{\circledR}$ program in their research to determine the value of green ENERGY STAR home designs in Fort Collins, Colorado. By its nature, the ENERGY STAR program offered an effective indicator of home energy efficiency by which to compare to standard, code-built homes. Their results showed that buyers, on average, were willing to pay $\$ 8.66 / \mathrm{ft}^{2}$ more because of the perceived value of the ENERGY STAR rating (Bloom et al. 2011). 
Kok and Kahn (2012) conducted a similar study on more than one million "green-labeled" homes (certified by the ENERGY STAR, Leadership in Energy \& Environmental Design, and GreenPoint Rated programs) in California. By holding all other housing characteristics constant, they concluded that a green label on a California home added a $9 \%$ premium to the sales price compared to the price of an equivalent standard-built home. Hoen et al. (2011) found "strong evidence that California homes with photovoltaic (PV) systems have sold for a premium over comparable homes without PV systems." RESNET (2014) and The Los Angeles Times (2011) referenced the results of a study conducted by the Earth Advantage Institute in Portland, Oregon, which concluded that new homebuyers were willing to pay an $8 \%$ premium (or up to $30 \%$ for previously owned homes) because of the perceived value of the homes. Their discussions also noted that certified homes spend approximately 18 fewer days on the market than comparable noncertified homes.

Similar conclusions have been drawn by other researchers in other locations around the country. It is becoming increasingly more accepted and confirmed with data that energy-efficient homes generally sell for a higher price and more quickly than code-standard homes. However, it currently is not known if energy-efficient homebuilders - specifically those in the market of Colorado Springs, Colorado - are seeing an effect from energy efficiency on their business performance relative to what standard builders are seeing. IBACOS used market share and sales velocity to define a builder's performance.

Because homeownership and housing sales are so interconnected with the rest of American society and economy, the timing, location, and economic conditions significantly impacted the results of this study. The Great Recession, from late 2007 to mid-2009 (Hall 2010), was a major event for the housing industry and therefore serves as context for this research. The Recession severely hurt American households, which experienced a 20\% average decline in wealth (Pew Research 2010). This study also found that, during the Recession, 55\% of the labor force experienced some type of work-related hardship. According to the Bureau of Labor Statistics, 8.8 million American jobs were lost between January 2008 and February 2010 (Goodman and Mance 2011). Not only did millions of Americans lose their jobs and experience other financial adversities, but the real estate and construction markets also took severe hits. The Pew Research study found that nearly half of the 2,967 homeowners it interviewed stated that their house values declined during the Recession; slightly more than half of the group said by "a lot" (Pew Research 2010). Likewise, homebuilders experienced a big hit to their businesses during the Recession, as evidenced by a 30\% drop in new home construction to a record low of 506,000 homes in 2010 (U.S.Economy.About.Com 2015). Among the major industries in the United States, construction was hit the hardest; its employment declined 30\% from 2007 to 2011 (U.S. Bureau of Labor Statistics 2015).

Each state and city was affected differently by the Great Recession. Although Colorado was not one of the states hit hardest by the Recession, it did experience significant economic losses (Rosenberg 2012). Specifically, Colorado Springs saw its most severe decline in job growth (almost 12,000 jobs in 2009) since 1991 (Summit Economics 2014). The unemployment rate was at record high values during and immediately after the Recession, reaching almost 10\% (Summit Economics 2014). Homeowner foreclosure filings also rose significantly, and single-family home building permits plummeted to about 1,000 per month (Summit Economics 2014). 
As many builders across the country lost business and even went bankrupt during the Great Recession, builders of more expensive energy-efficient homes might have been expected to experience a more severe decline as consumers continued to bear the financial weight of the failing economy. However, despite the trauma seen by the industry as a whole, studies suggest that energy-efficient homebuilders remained in business at a higher rate during the Recession than did builders of standard homes (McGraw Hill Construction 2013). Studies also show that post-Recession energy-efficient homebuilders are now thriving (McGraw Hill Construction 2013). According to a study released in 2014 by McGraw Hill Construction (2014), building energy-efficient homes became advantageous for builders as the Recession worsened, because it differentiated their products to attract more consumers in the failing market. Because homebuyers were still willing to pay a premium for more valuable products, energy-efficient homebuilders were able to remain in business throughout the hardships of the Recession (McGraw Hill Construction 2014). Thus, energy-efficient homes increasingly gained more market share through the Recession and maintained this momentum as the home industry recovered (McGraw Hill Construction 2014).

Now that the Great Recession technically has ended and the housing market is healing, consumers are interested in energy-efficient homes for additional reasons than in the past (NWI Times 2012; Greenville Online 2013). Buyers are recognizing the increasing cost of energy and the efficiency and affordability of energy-efficient homes; therefore, they are interested in the value and savings associated with energy-efficient homes (Greenville Online 2013). With this trend, McGraw Hill Construction (2014) expects that single-family energy-efficient homes will account for $26 \%$ to $33 \%$ of the housing market by 2016 , translating to $\$ 80$ to $\$ 101$ billion-a significant increase from the $\$ 37$ billion in 2013. It is important to builders and the general energy-efficient market to understand the groups of consumers interested in energy-efficient homes. Although IBACOS has anecdotal evidence about general consumer preferences in Colorado Springs, Colorado, these factors were not the focus of this research.

Colorado Springs, in accordance with its political leanings, may represent a worst-case scenario in terms of the positive impact energy ratings may have had on builders' business success. This may be particularly true if the homes were labeled as environmentally conscious. According to a Pew Research study, Colorado Springs is the fourth most politically conservative city in the United States (Pew Research 2010), and people who consider themselves politically conservative may be dissuaded from purchasing energy-efficient products despite any economic benefits simply because of the polarizing issue. Consumer political affiliation was not studied directly by IBACOS in this research; however, this factor may reasonably be assumed to have some influence on consumers' decisions there to buy homes that were HERS rated (Gromet et al. 2015). In a more liberal city, political affiliation would be reasonably assumed to have some motivating influence on consumers' decisions to purchase a HERS-rated home there, although perhaps the reasons for making this purchasing decision may be different than the reasons in a more conservative location. Homebuilders should understand such decision-making by consumers because it presents opportunities to focus marketing campaigns and to engage more effectively with their potential customers.

Builders, particularly those interested in moving toward energy-efficient building, need to understand the market value of producing energy-efficient homes as well as the consumer interest. Builders need to be able to expect a positive return on investment and to market their 
products effectively. The future advancement of energy-efficient homes partially depends on the demonstration of the market performance that builders will experience. The results of this study help make this apparent for Colorado Springs; likewise, the same methodology could be applied to other U.S. cities toward the development of a national database of potential market opportunities for energy-efficient homebuilders.

\subsection{Research Questions}

This project will answer the following research question: In the Colorado Springs, Colorado, new homes market, do builders of energy-efficient homes translate the investment in energy efficiency into better business performance than builders of less energy-efficient homes? Specific research questions include:

1. For builders that are HERS rating their homes, what is the significance of HERS ratings to their sales velocity and market share?

2. How did the prevalence of HERS ratings change during the Great Recession (2007 to 2009) and in the period immediately after the Great Recession (2010 to 2013)?

The results of this research provide lessons learned to help builders, HERS raters, and local municipalities make informed decisions about investing in the market growth of energy-efficient homes in Colorado Springs, Colorado, while informing a similar national audience on a methodology for developing similar lessons learned in other cities around the country. 


\section{Technical Approach}

\subsection{Data Sources}

All data collected for this study were for newly constructed homes in Colorado Springs, Colorado, and did not include data for existing homes. Three data sources were consulted in this research:

- Metrostudy

- EnergyLogic

- Built Green Colorado.

Metrostudy, ${ }^{1}$ a Hanley Wood company, is a housing market research firm that boasts the largest housing market information database in the United States. It compiles its data by physically visiting and inspecting subdivisions of new homes every calendar quarter and then includes additional information from other sources about future developments, demographics, deed records, and tax assessor records, as well as economic data and other data points related to the local and national economies. IBACOS obtained quarterly historical data from Metrostudy for all of Colorado Springs from 2005 through the second quarter of 2014, which included documentation of more than 25,000 individual home sales in the span of $9-1 / 2$ years. The data provide many important pieces of information such as:

- The types of homes and their active/build-out status

- The total number of homes within a particular subdivision and section

- The developers and builders within each subdivision

- Various metrics such as sale price, lot size, ZIP code, and homeowners association fees

- Hedonic characteristics such as parks, pools, tennis courts, and lakes

- Quarterly data for closings, starts, and inventory.

EnergyLogic, ${ }^{2}$ a residential energy-efficiency company in Colorado, is a leading provider of energy-efficiency services in the state. It performs a range of services for professionals in the residential building industry, including energy auditing and rating services for various programs (Leadership in Energy \& Environmental Design, ENERGY STAR, Passive House, Zero Energy Ready Homes, and more). EnergyLogic is the largest provider of home energy ratings in the Colorado Springs market, accounting for $80 \%$ to $90 \%$ of all rated properties in the city.

Although EnergyLogic is recognized as the largest rater in Colorado and the primary rater in Colorado Springs, IBACOS acknowledges that other smaller energy rating companies are performing energy ratings in Colorado Springs or, in some cases, the builders are performing the energy ratings in their houses. Therefore, the data collected from EnergyLogic used in this research do not represent a comprehensive list of all rated homes in Colorado Springs; however, the data include the majority of these homes.

\footnotetext{
${ }^{1}$ http://metrostudy.com/index.php

2 http://nrglogic.com/
} 
Built Green Colorado was a green building program in Colorado, concentrated in the Denver metropolitan area but offered throughout the state. The program used a checklist to certify that certain criteria were met as set forth by the program standards. A HERS rating threshold was an available path to certification in the Built Green Colorado program, as was ENERGY STAR certification. As such, the data provided by Built Green Colorado cross-references with all data provided by EnergyLogic. Built Green Colorado is no longer an active program.

To simplify the data set for this study, IBACOS focused the analysis on the data provided by EnergyLogic alone. It is important to acknowledge the context that the Built Green Colorado data provide, however, and IBACOS has used the data in an anecdotal and relational way to support the conclusions drawn from analysis of the other data provided by Metrostudy and EnergyLogic.

The ENERGY STAR for New Homes and the National Association of Home Builders (NAHB) Green programs are energy efficiency and "green" building programs sponsored by the U.S. Environmental Protection Agency and NAHB, respectively. ENERGY STAR requires HERS ratings to be performed on all certified homes, but NAHB Green does not require HERS ratings. Some new homes being constructed in Colorado Springs during the analysis period (2006 to 2013) were being certified to one or both of these programs; however, data were not obtained on the NAHB Green program. As such, these data are not specifically quantified or analyzed in this research. In particular, ENERGY STAR played a significant role in the number of HERS ratings that were performed in 2006 through 2013 as the program transitioned from one set of requirements (ENERGY STAR Version 2) to another, more rigorous set of requirements (ENERGY STAR Version 3).

\subsection{Data Aggregation}

IBACOS merged the energy data and market data into a single database as a means for comparison; the common element was the builder. The energy data were per home, but the market data were recorded as groups of lots within subdivisions. Therefore, the merged energy data were associated with the market data per builder within each subdivision.

The energy data that IBACOS obtained reached back to 2006 and included the HERS ratings for each individually rated home, whether or not the home was ENERGY STAR certified, and the date of certification. Although IBACOS obtained data prior to this date, those data were not included in the analysis because the HERS system underwent a major overhaul at that time; therefore, comparisons to other ratings are problematic.

The sampling interval of the market data was quarterly; the month and day of each rating were known. Therefore, the energy data were binned to the coarser quarterly interval for the comparison.

IBACOS grouped the data set for three time periods between 2005 and 2013, drawing the divisions along the lines of the Great Recession. Between 2005 and the middle of 2006, the housing market in Colorado Springs was still growing; from 2006 to the end of 2010, the market sharply contracted. Beginning in 2011 and continuing today, the market has undergone some recovery; some of the lost business was regained but is still at a fraction of the total activity seen prior to the Great Recession. 


\subsection{Points of Significance}

This study analyzed two categories for each builder: market performance and energy ratings. These two categories will be examined both individually and in comparison.

- Market performance. For a builder, the primary metrics of market performance are market share and sales velocity. The top 25 Colorado Springs builders in terms of closing volume were isolated to tell the story of the market because they represent the largest market segment and the majority of HERS ratings that were performed. The profitability of the builders was not measured because those data are difficult to obtain; however, those data would provide a useful metric for understanding the return on investment in energy efficiency.

- Energy ratings. Of importance to builders and energy-efficiency professionals is how to better leverage the benefits of energy efficiency and the impact from a business perspective of the related investments. ENERGY STAR and HERS are the leading metrics for home energy use and provide a basis of comparison that can simplify decision making. Energy ratings have evolved in their sophistication and methodology; HERS represents a flexible and calculated method of evaluation, whereas ENERGY STAR is more prescriptive and akin to a checklist. Perhaps the ability to meet a goal along many routes, as is the case with HERS, is preferred by builders.

Some builders may invest in having all their products HERS rated, but this is not common in Colorado Springs. Based on anecdotal evidence from Built Green Colorado and EnergyLogic, a Colorado Springs builder has likely experimented with HERS ratings or energy efficiency and offers these features as a subset of its product list. In some cases, the motivation for investment in these ratings is internal to the builder. More often, however, the motivation is external to the builder and comes directly from the developer of a subdivision where the builder is active.

IBACOS examined municipal building codes to determine the influence of regulations on the prevalence of energy ratings. However, this report focuses on the market conditions that lead builders to build energy-rated homes.

Section 3 shows that the drop-off in home sales as a result of the external market pressures of the Great Recession is the single largest event during the nearly decade-long period from which the data for this research were drawn. Of interest in this study is how HERS ratings may have played a role in the success of a builder or subdivision despite the drop-off.

Closing data speak in absolute terms and are useful to understand how a builder is performing over time. Closing data provide a sense of an individual builder's growth. Part of this study tries to illustrate builders' health now compared to the pre-Recession period.

When comparing builders, market share is an appropriate metric because it shows whether certain builders have self-differentiated and captured new territory from others over time. This study uses market share as a metric to show how the investment in energy efficiency (HERS ratings) may have influenced the market capture rate of a builder. 


\section{Results and Analysis}

\subsection{Home Energy Ratings in Colorado Springs}

The Great Recession of 2007 to 2009 had a profound effect on the housing market in Colorado Springs and therefore must be discussed as playing a major role in the energy rating industry. Figure 1 illustrates the profile of total closings per quarter in ZIP codes within the metropolitan area of Colorado Springs. From the beginning of 2005 through the second quarter of 2006, the city saw very high rates of home closings, averaging 1,274 per quarter. During 2008 through 2010, 2 years after the Recession began, the number of new homes closed per quarter had dropped by more than $64 \%$ to 453 . From 2010 onward, the city has experienced a steady increase in sales velocity; the second quarter of 2014 saw 662 closings, up from a low of 302 in the fourth quarter of 2010. The top 25 builders in the Colorado Springs market saw a 59\% decrease in the number of new homes closed per year following the fallout of the Great Recession. Of those 25 builders, 14 ceased operations in the city during the years since the Recession began.

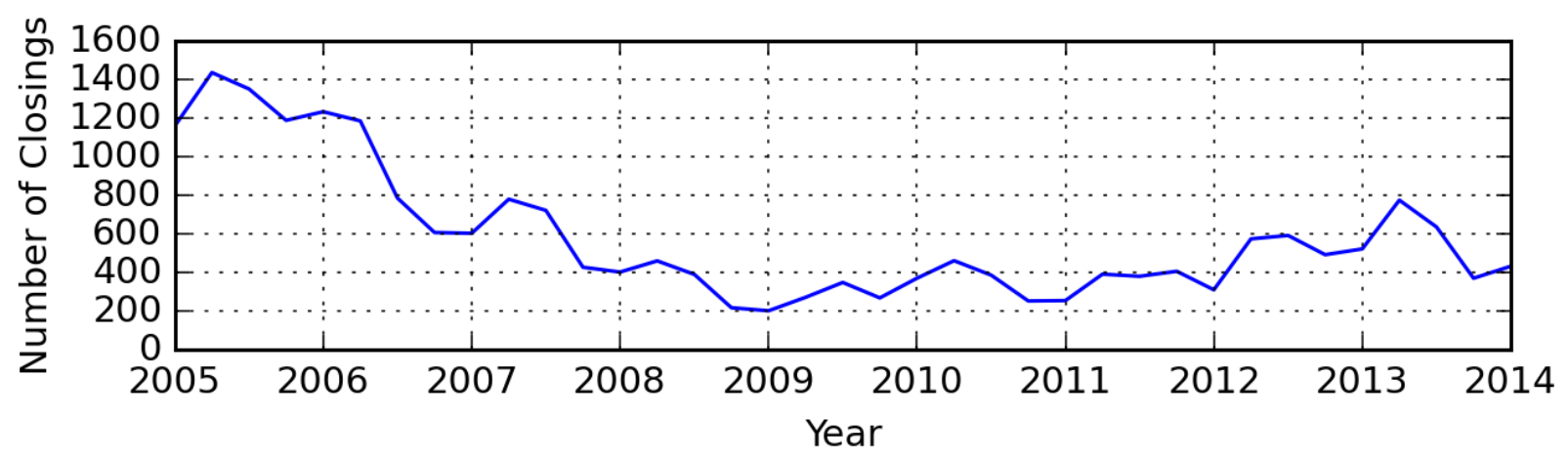

Figure 1. Number of new home closings per quarter in Colorado Springs, Colorado (2005-2013)

The energy ratings picture follows a different trend. Figure 2 documents the number of new homes receiving ENERGY STAR certification during the same time period.

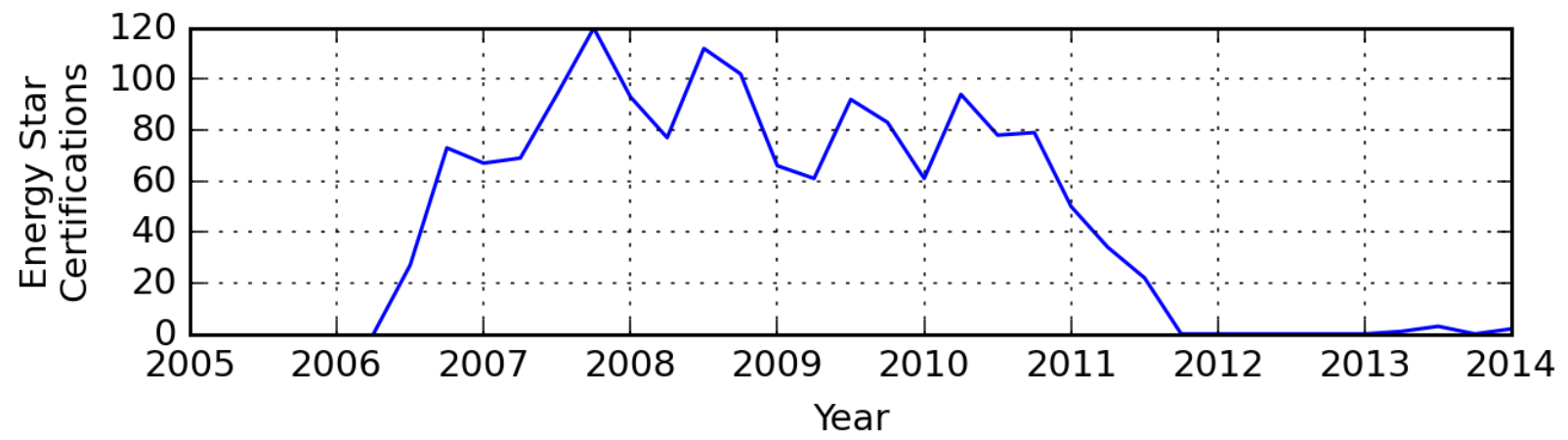

Figure 2. Number of ENERGY STAR certifications on new homes in Colorado Springs, Colorado (2006-2013)

As shown in Figure 3, the HERS ratings profile (number of homes receiving a HERS rating) for the same period has a striking difference: From 2006 through 2010, nearly all homes that 
received a HERS rating also were ENERGY STAR certified. However, ENERGY STAR was virtually abandoned in the region after 2011.

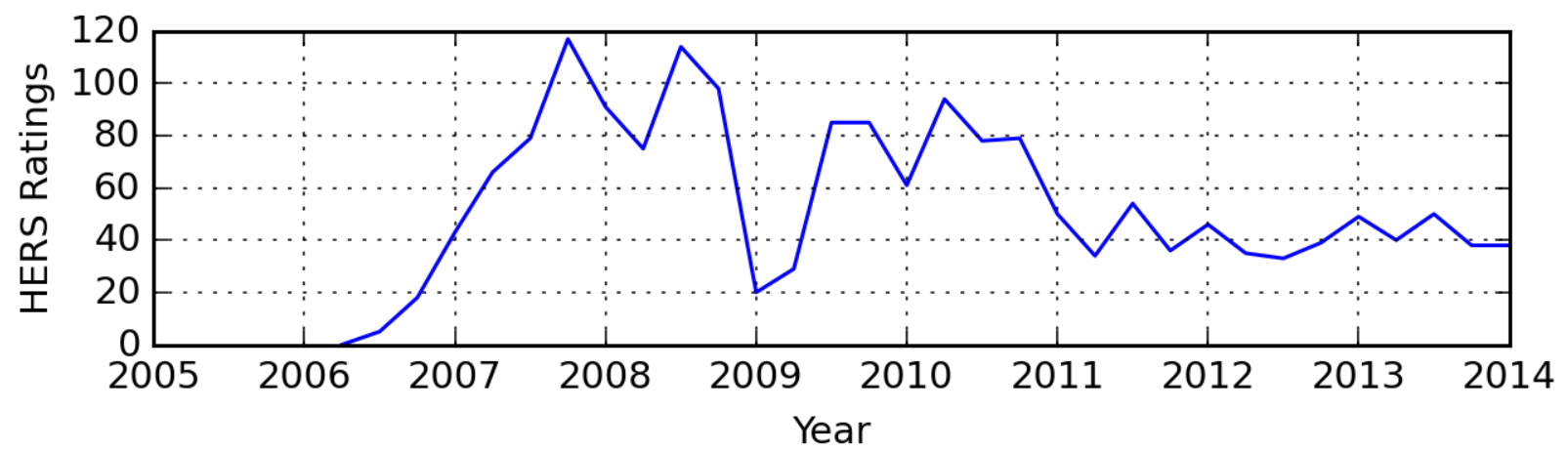

Figure 3. Number of HERS-rated new homes in Colorado Springs, Colorado (2006-2013)

The effect of ENERGY STAR Version 3, which began in 2010 and introduced a higher level of rigor to the program, seems to be significant in the Colorado Springs market. The number of HERS ratings fell off steeply_-down 50\% after 2010 — which mirrors the drop-off in ENERGY STAR certifications during the same period and seems likely due to the advent of Version 3 of the program. Although the ENERGY STAR for Homes program saw rapid growth nationally between 2006 and 2010, more recently it has fallen off. In 2006, the ENERGY STAR program held more than a $12 \%$ market share of newly constructed homes (NETL 2008). This number grew to more than 24\% in 2010 (NETL 2012). However, in 2014, the number dropped sharply to a $12 \%$ market share, even though the housing market began to show signs of strong growth.

Many energy utilities that were offering incentives for ENERGY STAR compliance eliminated those incentives with Version 3 of the program because of the increased number of nonenergy requirements. Anecdotal evidence from EnergyLogic and Built Green Colorado confirms similar reasons for the drop in ENERGY STAR certifications in Colorado Springs.

Comparing data about HERS ratings to the economic data from Metrostudy, two profiles emerge. As indicated in Figure 4, during the peak of the decline in home sales between 2006 and 2008, a higher percentage of new homes were HERS rated than prior to the Recession. Since 2010, when ENERGY STAR certifications began to drop, HERS ratings have been relatively flat or in a steady decline even as new home sales have picked up. 


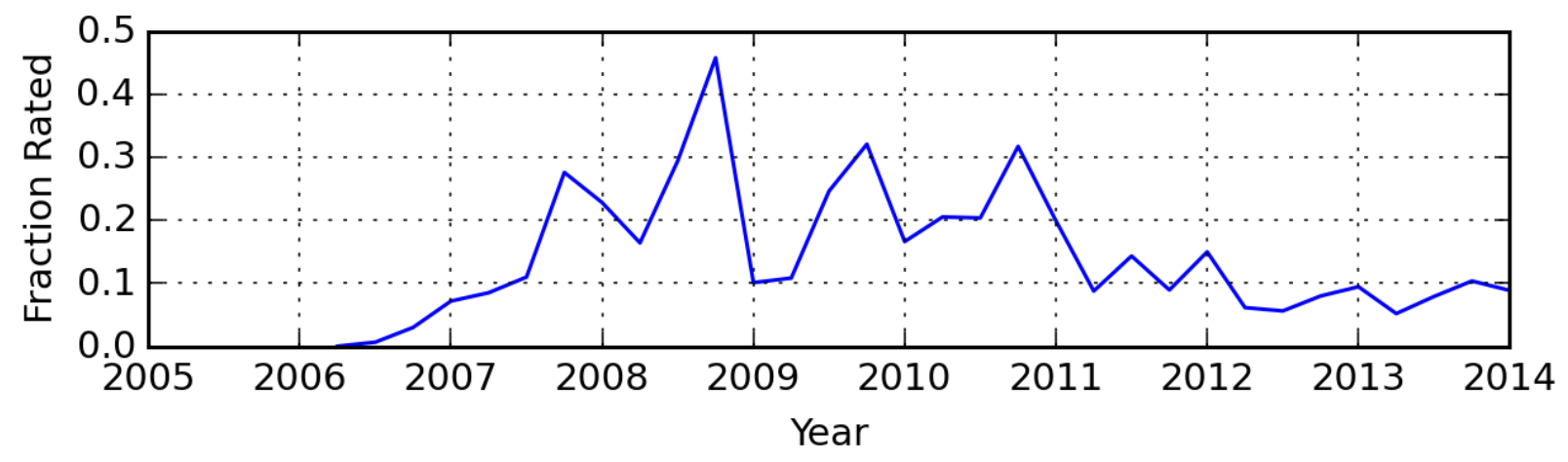

Figure 4. Fraction of new homes that were HERS rated in Colorado Springs, Colorado (2006-2013)

Not all builders that are building energy-efficient homes do so through the HERS mechanism. One prominent builder that built, on average, more than eight homes per quarter in 2013 did not have HERS ratings performed on its homes. However, the builder's website indicates that it did use NAHB Certified Green Professional oversight, which also bolsters the observation that builders who build energy-efficient homes fared well through the Great Recession.

\subsection{Variations in Market Share of Builders and Energy Efficiency}

The general negative sales trend during the Great Recession held true for nearly all builders. However, these negative effects of the Recession may have been dampened by an investment in home energy ratings. Figure 5 and Figure 6 document the number of builders who built at least 20 homes during the analysis period in Colorado Springs and, of those, the number that completed at least two energy ratings during each quarter. Those builders doing only one rating were ignored because they were likely "demo" ratings and did not represent energy efficiency as integral to their building practices.

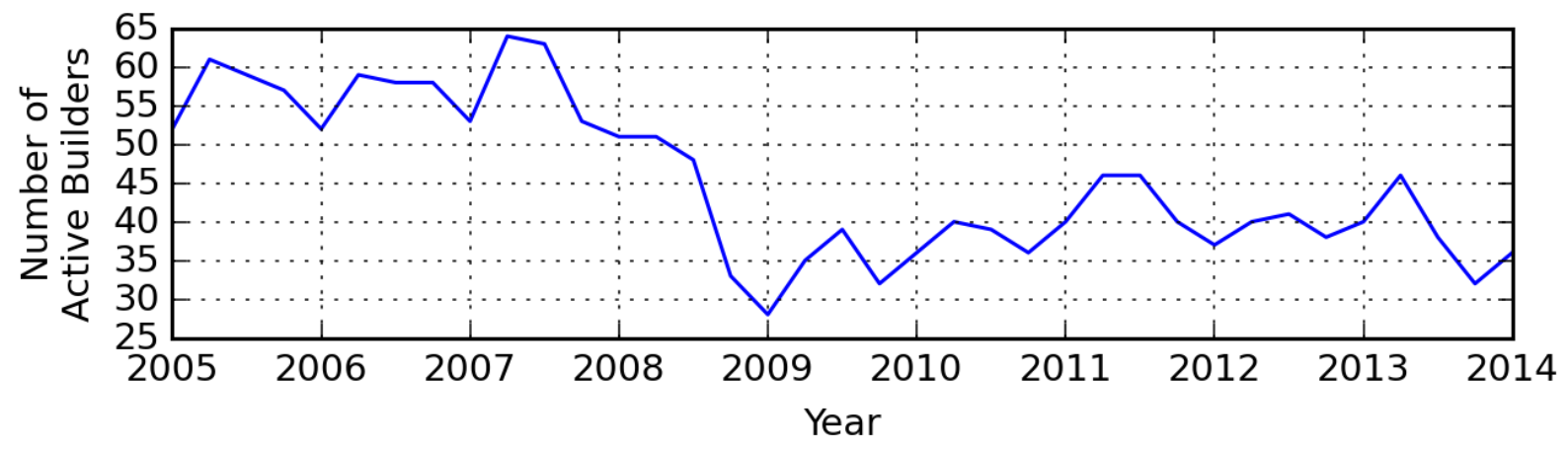

Figure 5. Number of active builders in Colorado Springs, Colorado (2005-2013) 


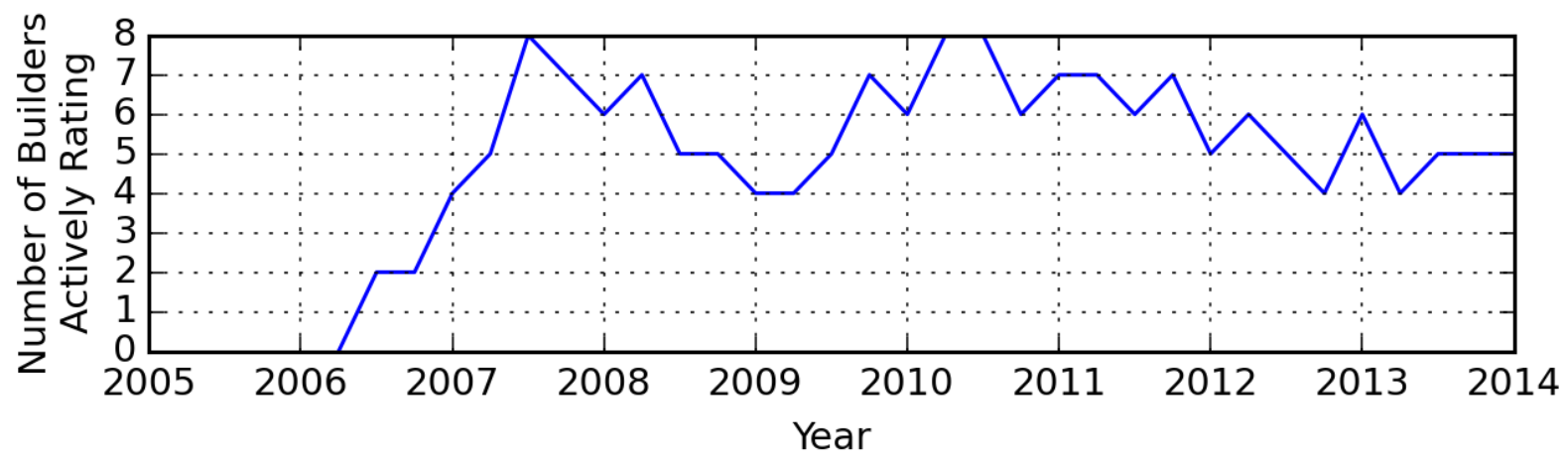

Figure 6. Number of builders actively having HERS ratings performed in Colorado Springs, Colorado (2006-2013)

Twelve of the top 25 builders from 2005 by closing volume no longer operate in Colorado Springs or have gone out of business, and one dropped out of the top 25 . Only one of those builders performed energy ratings of its product, and that builder rated only $9 \%$ of its homes. Conversely, 11 of the top 25 builders by total closings in 2013 did not close any homes in 2006, and two builders entered the top 25. Two of these new builders to Colorado Springs performed energy ratings of their products. Neither those builders who left the market nor those who recaptured the departed market share performed energy ratings at a significant level. In other words, energy ratings did not differentiate builders in their ability to capture new territory postRecession. Table 1 summarizes these data.

Table 1. Division of Market between Energy-Efficient and Standard Builders, Pre- and PostRecession

\begin{tabular}{l|c|c|c}
\hline & $\begin{array}{c}\text { Top 25 2006 } \\
\text { (Combined } \\
\text { Market Share) }\end{array}$ & $\begin{array}{c}\text { Still in Business } \\
\mathbf{2 0 1 3} \text { (Combined } \\
\text { Market Share) }\end{array}$ & $\begin{array}{c}\text { New to Market } \\
\text { Post-Recession } \\
\text { (Combined Market Share) }\end{array}$ \\
\hline $\begin{array}{l}\text { Performed } \\
\text { Energy Ratings } \\
\begin{array}{l}\text { Did Not Perform } \\
\text { Energy Ratings }\end{array}\end{array}$ & $7(31.3 \%)$ & $6(24.2 \%)$ & $2(13.6 \%)$ \\
\hline
\end{tabular}

A two-tailed Fisher Exact test confirmed the statistical significance of energy ratings and a builder's survivability based on whether the builder fell into the energy rating category. There is a $97 \%$ chance the builder's ability to survive was influenced by the builder having performed energy ratings. Other factors, such as a commitment to higher quality, may have influenced the builder's survival; however, the most resilient builders in Colorado Springs performed energy ratings consistently. Table 2 documents the inputs to the test. 
Table 2. Survival of Builders Post-Recession and Whether They Performed Energy Ratings

\begin{tabular}{l|c|c}
\hline & Survived & Left Market \\
\hline Performed Energy Ratings & 6 & 1 \\
\hline Did Not Perform Energy Ratings & 6 & 12 \\
\hline
\end{tabular}

Figure 7 shows the percentage of builders that performed at least two energy ratings per quarter. Any builder that performed only one energy rating was excluded, because many builders do demo ratings and do not represent those that actively engage with raters to build energy-efficient homes. Although a high percentage of builders was active during the Great Recession, more recently the trend has been to revert to code-driven practices. According to EnergyLogic and supported by the data, the builder community of Colorado Springs simply does not perceive that energy ratings are necessary to sell homes.

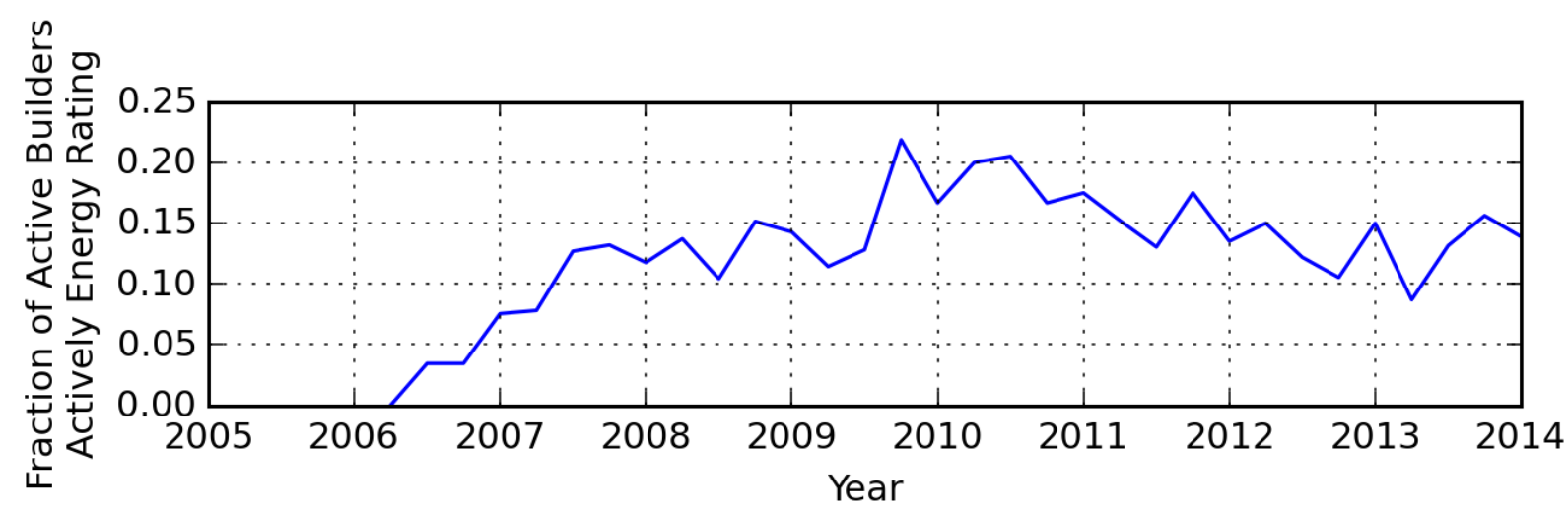

Figure 7. Percentage of active builders performing at least two HERS ratings in Colorado Springs, Colorado (2006-2013) 


\section{Conclusions}

This report sought to address the following question: Do builders of energy-efficient homes translate the investment in energy efficiency into better business performance than builders of less energy-efficient homes?

To address this question, this report focused on the Colorado Springs, Colorado, new homes market to determine if builders of HERS-rated homes translated that investment into better business performance than builders of non-HERS-rated homes. Specific research questions included the following:

1. For builders that are HERS rating their homes, what is the significance of HERS ratings to their sales velocity and market share?

2. How did the prevalence of HERS ratings change during the Great Recession (2007 to 2009) and in the period immediately after the Great Recession (2010 to 2013)?

Based on the results of the analysis conducted on new-home market data from Colorado Springs, Colorado, from 2006 to 2014, the following conclusions were reached:

- HERS ratings had a positive correlation to builder survival during the Great Recession of 2007 to 2009.

- The observed positive correlation is significant at a $95 \%$ or higher confidence level (as shown with a Fisher Exact test) on the survivability of builders and whether they performed energy ratings.

- ENERGY STAR has virtually disappeared from the Colorado Springs market since Version 3 of the program was introduced. HERS ratings have taken over as the dominant energy-efficiency "validation" system. (NAHB Green has a strong presence with one builder.)

The positive correlation between the practice of HERS rating of homes and builder survival during the Great Recession could have several causes. One obvious cause could be consumer demand for more energy-efficient homes, although it is unclear whether the Colorado Springs consumer is asking for energy efficiency as a priority in that market. Another possible cause is that builders participating in the HERS rating process, which requires a third-party verifier that inspects sites and tests the homes during construction, are paying greater attention to construction details and to the quality of their homes and are somehow translating those details into greater market appeal to their potential buyers. The data available to this study did not specifically address this factor; however, anecdotal evidence from local professionals familiar with this market suggests this could be a possible cause for some builders' success.

One additional question that emerges at this point is whether a builder marketed the energy efficiency of its homes to potential buyers and, if so, how effective was that marketing in driving new home sales. This study did not address the marketing of energy efficiency or HERS, but certainly this factor would have a significant effect on the sales of new homes and would provide greater understanding of the reasons HERS ratings had such an effect on builder survival during the Great Recession. For example, a builder may have marketed its homes as being energy 
efficient without having its homes HERS rated or verified through some other energy-efficiency program (e.g., NAHB Green), and this "false advertising" may have driven consumer decisions, regardless of the builder's actual participation in such a program.

To gain greater insight into the cause of this positive correlation between HERS ratings and builder success, several avenues of research could be further explored. First, builders in the Colorado Springs market could be engaged to comment directly about this correlation and to provide their insights into the HERS rating process and their survival during the Great Recession. Also, builders could offer insights into the marketing of HERS and energy efficiency in general and could speak to the perceived effect of this marketing on their buyers' decisions to purchase homes.

As ENERGY STAR has disappeared from the Colorado Springs market and HERS ratings have generally plateaued, it is curious why the number of builders performing HERS ratings (and the total number of HERS-rated homes) has not increased more dramatically, given the obvious correlation to survival during the tough economic times of the Great Recession. It would seem to be a strong business move to incorporate HERS ratings, at a minimum, given this positive correlation to business success. However, given the improved market, it may be less necessary to invest in additional verification efforts because homes are selling regardless of energy performance. Perhaps the current building and energy codes are sufficient for most builders to validate the quality and performance of their homes. Perhaps the local buyers have no preference.

Another area that requires a more thorough analysis is how the promotion of the rating programs by government and others may or may not have had an impact. The seeming correlation between this kind of promotional support and the uptake of certifications by the building industry is worth more investigation. The data suggest a high value to stakeholders in these efforts to stimulate public and industry awareness and to bolster the rating industry.

Although not analyzed rigorously, the current polarized political climate, which is particularly split on the issue of climate change, may play a role in the recent rejection of energy-efficient certification. Perhaps the politics of Colorado Springs contribute to why ENERGY STAR - a strong brand - may suffer from too much recognition because of the trend (identified by Gromet et al. 2015) for conservatives to reject products labeled as "green." Builders seeking to build energy-efficient homes in the Colorado Springs market may take into account this political climate when structuring their message to consumers. A focus on cost savings and efficiency rather than the environmental benefit may better sell their rated homes. The ratings may be less important than what they mean: lower utility bills, greater comfort, and higher quality. These questions were not studied directly in this research but offer future avenues for exploration. It is yet to be seen whether builders that continue and begin to invest in energy ratings will obtain market share from those continuing code-driven businesses.

To better understand a builder's decision to participate in an energy-efficiency program (e.g., HERS or ENERGY STAR), it would be useful to investigate whether participation in those programs leads to greater builder attention to quality and whether this improved quality is reflected in their business success (e.g., through improved marketing success, improved customer satisfaction, reduced cycle time). Or perhaps the opposite is true, in that a quality 
builder is more likely to participate in an energy-efficiency program to provide third-party validation of this quality.

Another factor is cost. In a cost-competitive market, any new investment by a builder must have a clear return in terms of increased revenue and profit. It would seem obvious that, given the drop-off in ENERGY STAR and the plateau in HERS ratings, energy efficiency is seen less as a valuable return on investment. However, given the positive correlation between HERS ratings and builder survivability during the Great Recession, this is curious. As Colorado Springs emerges from the Recession, builders seem to be reverting to a code-driven practice, despite potentially benefitting from their participation in energy rating during the Recession. Are they wrong? 


\section{References}

Bloom, B., M.E.C, Nobe, and M.D. Nobe. 2011. "Valuing Green Home Designs: A Study of ENERGY STAR ${ }^{\circledR}$ Homes.” Journal of Sustainable Real Estate, 3(1). www.josre.org/wpcontent/uploads/2012/09/Valuing_Green_Home_Designs_ENERGY-STAR-Homes-JOSRE_v361.pdf.

Galuppo, L.A., and C. Tu. 2010. "Capital Markets and Sustainable Real Estate: What Are the Perceived Risks and Barriers?” Journal of Sustainable Real Estate, 2(1). http://galuppolaw.com/news/files/cmsre.pdf.

Goodman, C., and S. Mance. 2011. "Employment Loss and the 2007-09 Recession: An Overview." Monthly Labor Review. Washington, DC: U.S. Bureau of Labor Statistics. www.bls.gov/opub/mlr/2011/04/art1full.pdf.

Greenville Online. 2013. "Green Homes Gain Popularity as Customers Seek Cost Savings." www.greenvilleonline.com/article/BS/20130914/NEWS07/309140009/Green-homes-gainpopularity-customers-seek-cost-savings.

Gromet, D., H. Kunreuther, and R. Larrick. 2015. "Consumer Responses to Energy Efficiency: Political Ideology Affects Energy-Efficiency Attitudes and Choices." New York: Center for Research on Environmental Decisions, Earth Institute, Columbia University. http://cred.columbia.edu/consumer-responses-to-energy-efficiency-featured/.

Hall, R.E. 2010. "Program Report: Economic Fluctuations and Growth." NBER Reporter OnLine 2010, No. 1. Cambridge, MA: National Bureau of Economic Research. www.nber.org/reporter/2010number1/.

Hoen, B., R. Wiser, P. Cappers, and M. Thayer. 2011. An Analysis of the Effects of Residential Photovoltaic Energy Systems on Home Sale Prices in California (Technical Report). Berkeley, CA: Ernest Orlando Lawrence Berkeley National Laboratory. http://emp.lbl.gov/sites/all/files/lbnl-4476e.pdf.

Kok, N., and M.E. Kahn. 2012. The Value of Green Labels in the California Housing Market: An Economic Analysis of the Impact of Green Labeling on the Sales Price of a Home. Washington, DC: U.S. Green Building Council.

www.usgbc.org/sites/default/files/ValueofGreenHomeLabelsStudy_July2012.pdf.

Lande, C.D. 2007. "Homeowner Views on Housing Market Valuation of Energy Efficiency: An Empirical Investigation." Theses, Dissertations, Professional Papers. Paper 523. Missoula, MT: University of Montana. http://scholarworks.umt.edu.

Los Angeles Times. 2011. "Energy-Efficient Homes Seem to Sell Faster, Fetch Higher Prices." Los Angeles Times, August 28, 2011. http://articles.latimes.com/2011/aug/28/business/la-fiharney-20110828.

McGraw-Hill Construction. 2013. "Green Outlook 2013." http://analyticsstore.construction.com/smartmarket-reports/green-outlook-2013.html. 
McGraw-Hill Construction. 2014. "SmartMarket Report: Green Multifamily and Single Family Homes: Growth in a Recovering Market."

http://analyticsstore.construction.com/2014GreenHomesSMR.html.

NETL. 2008. 2008 Buildings Energy Data Book. Silver Spring, MD: D\&R International, Ltd. http://buildingsdatabook.eere.energy.gov/docs\%5CDataBooks\%5CSEP 2008 BEDB.pdf.

NETL. 2012. 2011 Buildings Energy Data Book. Silver Spring, MD: D\&R International, Ltd. http://buildingsdatabook.eren.doe.gov/docs/DataBooks/2011_BEDB.pdf.

NWI Times. 2012. "Buyers' Tastes Have Changed After the Recession: Accessibility, Sustainability and Practicality Rank High on Wish Lists." Munster, IN: NWI Times. http://www.nwitimes.com/lifestyles/home-and-garden/buyers-tastes-have-changed-after-therecession-accessibility-sustainability-and/article a3fb2b3a-2223-5176-b40c-b305e713351e.html.

Pew Research. 2010. "How the Great Recession Has Changed Life in America." Washington, DC: Pew Research Center. www.pewsocialtrends.org/2010/06/30/how-the-great-recession-haschanged-life-in-america/.

RESNET. 2013. "Mortgage Industry National Home Energy Rating Standards.” Oceanside, CA: Residential Energy Services Network. www.resnet.us/standards/RESNET_Mortgage_Industry_National_HERS_Standards.pdf.

RESNET. 2014. "Sell Your Home Fast and Easily with a HERS ${ }^{\circledR}$ Index Score." Oceanside, CA: Residential Energy Services Network. www.resnet.us/library/index-score-can-help-sell-home/.

Rosenberg, Y. 2012. "Great Recession Hurt Some States More Than Others." The Fiscal Times. June 22, 2012. www.thefiscaltimes.com/Articles/2012/06/22/Great-Recession-Hurt-SomeStates-More-Than-Others.

Summit Economics. 2014. "Springs Monthly Economic Indicators: Colorado Springs Metro Area, January 1991 to July 2014.” Summit Economics. www.summiteconomics.com.

U.S. Bureau of Labor Statistics. 2015. "Employment, Hours, and Earnings from the Current Employment Statistics Survey (National)." Washington, DC: U.S. Bureau of Labor Statistics. http://data.bls.gov/timeseries/CES2000000001?data tool=XGtable.

U.S.Economy.About.Com. 2015. "New Home Builders: Top 10 and How They Affect the Economy.” http://useconomy.about.com/od/glossary/g/New-Home-Builder.htm. 
